\title{
Evidence that the major degradation product of glucose-dependent insulinotropic polypeptide, GIP(3-42), is a GIP receptor antagonist in vivo
}

\author{
V A Gault, J C Parker, P Harriott ${ }^{1}$, P R Flatt and F P M O'Harte \\ School of Biomedical Sciences, University of Ulster, Cromore Road, Coleraine, N Ireland BT52 1SA, UK \\ ${ }^{1}$ Centre for Peptide and Protein Engineering, School of Biology and Biochemistry, The Queen's University of Belfast, Medical Biology Centre, Belfast, \\ $\mathrm{N}$ Ireland BT9 7BL, UK \\ (Requests for offprints should be addressed to V A Gault; Email: va.gault@ulster.ac.uk)
}

\begin{abstract}
The incretin hormone glucose-dependent insulinotropic polypeptide (GIP) is rapidly degraded in the circulation by dipeptidyl peptidase IV forming the N-terminally truncated peptide GIP(3-42). The present study examined the biological activity of this abundant circulating fragment peptide to establish its possible role in GIP action. Human GIP and GIP(3-42) were synthesised by Fmoc solid-phase peptide synthesis, purified by HPLC and characterised by electrospray ionisation-mass spectrometry. In GIP receptor-transfected Chinese hamster lung fibroblasts, GIP(3-42) dose dependently inhibited GIP-stimulated $\left(10^{-7} \mathrm{M}\right)$ cAMP production (up to $75 \cdot 4 \pm 5 \cdot 4 \% ; P<0 \cdot 001)$. In BRIN-BD11 cells, GIP(3-42)
\end{abstract}

was significantly less potent at stimulating insulin secretion (1.9- to 3.2-fold; $P<0 \cdot 001)$, compared with native GIP and significantly inhibited GIP-stimulated $\left(10^{-7} \mathrm{M}\right)$ insulin secretion with maximal inhibition $(48 \cdot 8 \pm 6 \cdot 2 \%$; $P<0 \cdot 001)$ observed at $10^{-7} \mathrm{M}$. In $(o b / o b)$ mice, administration of GIP(3-42) significantly inhibited GIPstimulated insulin release $(2 \cdot 1$-fold decrease; $P<0 \cdot 001)$ and exaggerated the glycaemic excursion $(1 \cdot 4$-fold; $P<0 \cdot 001)$ induced by a conjoint glucose load. These data indicate that the N-terminally truncated GIP(3-42) fragment acts as a GIP receptor antagonist, moderating the insulin secreting and metabolic actions of GIP in vivo.

Journal of Endocrinology (2002) 175, 525-533

\section{Introduction}

Glucose-dependent insulinotropic polypeptide (GIP) is a 42 amino acid peptide hormone (Jörnvall et al. 1981) synthesised in enteroendocrine K-cells (Buchan et al. 1978) via the proteolytic processing of a larger precursor polypeptide (Takeda et al. 1987). Like its sister incretin hormone, glucagon-like peptide-1 (GLP-1), GIP potentiates meal-induced insulin secretion (Creutzfeldt \& Ebert 1985) which together with extrapancreatic actions on muscle and adipose tissue makes a significant contribution to the regulation of postprandial glucose homeostasis (Morgan 1996).

To date, numerous structure-function studies have attempted to elucidate the bioactive domain(s) within the GIP molecule (Moroder et al. 1978, Carlquist et al. 1984, Maletti et al. 1986, Maletti et al. 1987, Pederson et al. 1990, Gelling et al. 1997, Hinke et al. 2001). Truncation of GIP at the C-terminus to GIP(1-39) (Sandberg et al. 1986) or GIP(1-38) (Moroder et al. 1978) produced fragments with comparable activity to the native peptide. Further truncation to $\operatorname{GIP}(1-31)$ produced a fragment, which displayed weaker receptor binding affinity, but still retained an equal cAMP stimulating potency compared with native GIP (Maletti et al. 1987). More recently, GIP(1-30)amide and native GIP were shown to be equipotent at stimulating insulin secretion (Morrow et al. 1996), although GIP(1-30)amide displayed a significantly reduced somatostatinotropic activity (Pederson et al. 1990), indicating that part of the C-terminal sequence is critical for its acid inhibitory activity (Rossowski et al. 1992).

The role of the N-terminus for GIP action evaluated by fragment peptide analysis suggested that the bioactive site resided between residues 19 and 30 (Morrow et al. 1996). However, these results were in apparent conflict with studies using Des-Tyr ${ }^{1}-\mathrm{Ala}^{2}$-GIP (Schmidt et al. 1987) and synthetic GIP(4-42) (Maletti et al. 1986) which exhibited similar receptor binding affinity to the native peptide, but displayed greatly reduced insulinotropic activity. Subsequently, another bioactive domain was suggested to reside within amino acid residues 1-14 (Hinke et al. 2001), but the overall importance of the N-terminal $\mathrm{Tyr}^{1}-\mathrm{Ala}^{2}$ dipeptide of GIP in regulating biological activity was demonstrated by Brown et al. (1981). Thus early studies using GIP(3-42) originally 
isolated from porcine intestinal extracts demonstrated that this truncated peptide lacked insulinotropic activity, therefore confirming the necessity of an intact $\mathrm{N}$-terminus for retention of biological activity (Brown et al. 1981).

Subsequent studies with GIP(3-42) have shown it to be devoid of any antagonistic activity (Schmidt et al. 1987), however, parallel studies using the sister incretin hormone GLP-1 have recently shown that the truncated GLP-1(9-36)amide fragment may act as an antagonist (Grandt et al. 1994, Knudsen \& Pridal 1996). Furthermore, GLP-2 (3-33) which also arises from proglucagon processing in the intestine may also act as a competitive antagonist (Thulesen et al. 2002). Recently, using a newly developed radioimmunoassay, GIP(3-42) has been identified as the major component of endogenous GIP immunoreactivity in human plasma (Deacon et al. 2000). This arises from degradation of GIP by the ubiquitous enzyme dipeptidyl peptidase IV (DPP IV) highlighting the need for further evaluation of the possible antagonist actions of GIP(3-42). Accordingly, the current study has examined the in vitro effects of GIP(3-42) on GIP-stimulated cyclic AMP (cAMP) production and insulin secretion together with in vivo effects in a commonly employed animal model of type 2 diabetes.

\section{Materials and Methods}

\section{Reagents}

High performance liquid chromatography (HPLC) grade acetonitrile was obtained from Rathburn (Walkersburn, Scotland). Sequencing grade trifluoroacetic acid (TFA) was obtained from Aldrich (Poole, Dorset, UK). Isobutylmethylxanthine (IBMX), adenosine $3^{\prime}, 5^{\prime}$-cyclic monophosphate (cAMP) and adenosine 5'-triphosphate (ATP) were all purchased from Sigma (Poole, Dorset, UK). Fmoc-protected amino acids were from Calbiochem Novabiochem (Beeston, Nottingham, UK). RPMI 1640 and DMEM tissue culture medium, fetal calf serum, penicillin and streptomycin were all purchased from Gibco (Paisley, Strathclyde, Scotland). The chromatography columns used for cAMP assay, Dowex AG $50 \mathrm{WX}$ and neutral alumina AG7 were obtained from Bio-Rad (Alpha Analytical, Larne, N. Ireland). All water used in these experiments was purified using a Milli-Q, water purification system (Millipore, Milford, MA, USA). All other chemicals used were of the highest purity available.

\section{Peptide synthesis and purification}

GIP and GIP(3-42) were sequentially synthesised on an Applied Biosystems automated peptide synthesiser (model 432A) using standard solid-phase Fmoc protocols (Fields \& Noble 1990), starting from a pre-loaded Fmoc-GlnWang resin. The following side chain protected amino acids were used, Fmoc-Gln(Trt)-OH, Fmoc-Thr(Trt)$\mathrm{OH}$, Fmoc-His(Trt)-OH, Fmoc-Asn(Trt)-OH, FmocSer(Trt)-OH, Fmoc-Lys(Boc)-OH, Fmoc-Trp(Boc)$\mathrm{OH}, \quad$ Fmoc-Asp $(\mathrm{OtBu})-\mathrm{OH}$ and Fmoc-Tyr $(\mathrm{OtBu})-$ $\mathrm{OH}$. Deprotection and cleavage of the peptide from the resin was by trifluoroacetic acid:water:thianisole:ethanediol (90:2 $5: 5: 2 \cdot 5$, a total volume of $20 \mathrm{ml} / \mathrm{g}$ resin), the resin was removed by filtration and the filtrate volume was decreased under reduced pressure. Dry diethyl ether was slowly added until a precipitate was observed. The precipitate was collected by low-speed centrifugation, resuspended in diethyl ether and centrifuged again, the procedure being carried out five times. The resulting pellets were then dried in vacuo and judged pure by reversed-phase HPLC on a Waters Millenium 2010 chromatography system (Software version 2·1·5).

\section{Electrospray ionisation-mass spectrometry (ESI-MS)}

HPLC-purified GIP and GIP(3-42) peptides were dissolved (approximately $400 \mathrm{pM}$ ) in $100 \mu \mathrm{l}$ water and applied to an LCQ benchtop LC mass spectrometer (LC/MS) (Finnigan MAT, Hemel Hempstead, UK). Samples (20 $\mu$ ldirect loop injection) were applied at a flow rate of $0.2 \mathrm{ml} / \mathrm{min}$, under isocratic conditions in $35 \%(\mathrm{v} / \mathrm{v})$ acetonitrile/water. Mass spectra were obtained from the quadripole ion trap mass analyser and spectra collected using full ion scan mode over the mass-to-charge $(\mathrm{m} / z)$ range 150-2000. The molecular masses of each fragment were determined using prominent multiple charged ions using the following equation: $M_{\mathrm{r}}=i M_{\mathrm{i}}-i M_{\mathrm{h}}$ (where $M_{\mathrm{r}}$ is molecular mass, $M_{\mathrm{i}}$ is $m / z$ ratio, $i$ is the number of charges and $M_{\mathrm{h}}$ is the mass of a proton).

\section{Cells and tissue culture}

Chinese hamster lung (CHL) cells transfected with the human GIP receptor (Gremlich et al. 1995) were cultured in DMEM tissue culture medium containing 10\% (v/v) fetal calf serum and $1 \%(\mathrm{v} / \mathrm{v})$ antibiotics $(100 \mathrm{U} / \mathrm{ml}$ penicillin, $0.1 \mathrm{mg} / \mathrm{ml}$ streptomycin). BRIN-BD11 cells were cultured in sterile tissue culture flasks (Corning, Glass Works, UK) using RPMI-1640 tissue culture medium containing $10 \%(\mathrm{v} / \mathrm{v})$ fetal calf serum, $1 \%(\mathrm{v} / \mathrm{v})$ antibiotics (100 $\mathrm{U} / \mathrm{ml}$ penicillin, $0 \cdot 1 \mathrm{mg} / \mathrm{ml}$ streptomycin) and $11.1 \mathrm{mM}$ glucose. The origin and characteristics of BRIN-BD11 cells have been described previously (McClenaghan et al. 1996). The cells were maintained at $37^{\circ} \mathrm{C}$ in an atmosphere of $5 \% \mathrm{CO}_{2}$ and $95 \%$ air using a LEEC incubator (Laboratory Technical Engineering, Nottingham, UK).

\section{In vitro studies}

Effects on cAMP production were evaluated as detailed elsewhere (Gault et al. 2002). Briefly, transfected CHL 
cells plated in 12-well plates were loaded with $2 \mu \mathrm{Ci}$ tritiated adenine (TRK311, Amersham) for $6 \mathrm{~h}$ at $37^{\circ} \mathrm{C}$. The cells were then exposed for $10 \mathrm{~min}$ at $37^{\circ} \mathrm{C}$ to forskolin (FSK, $10 \mu \mathrm{M})$ or varying concentrations of $\operatorname{GIP}(3-42)$ in the absence or presence of GIP $\left(10^{-7} \mathrm{M}\right)$. After removal of the medium, cells were lysed and intracellular tritiated cAMP separated on Dowex and alumina exchange resins as described previously (Widmann et al. 1993).

Insulin releasing activity was measured in BRIN-BD11 cells as described previously (Gault et al. 2002). In brief, BRIN-BD11 cells seeded into 24-well plates were allowed to attach overnight at $37^{\circ} \mathrm{C}$. After pre-incubation (40 $\mathrm{min}$ ) in $1.1 \mathrm{mM}$ glucose, acute tests for insulin release were performed $(n=8)$ at $5.6 \mathrm{mM}$ glucose using various concentrations of GIP(3-42) in the absence and presence of GIP $\left(10^{-7} \mathrm{M}\right)$. After 20 min incubation, insulin concentrations were measured by radioimmunoassay (Flatt \& Bailey 1981).

\section{In vivo biological activity}

Plasma glucose and insulin responses were evaluated using 14- to 18-week-old (ob/ob) mice (Bailey \& Flatt 1982) following intraperitoneal (i.p.) injection of GIP or GIP(342) $(25 \mathrm{nmol} / \mathrm{kg}$ body weight $)$ immediately following the combined injection of GIP ( $25 \mathrm{nmol} / \mathrm{kg}$ body weight) with glucose $(18 \mathrm{mmol} / \mathrm{kg}$ body weight). All test solutions were administered to $18 \mathrm{~h}$ fasted mice in a final volume of $8 \mathrm{ml} / \mathrm{kg}$ body weight. Blood samples were collected at the times indicated from the cut tip of the tail vein of conscious mice into chilled fluoride/heparin microcentrifuge tubes (Sarstedt, Nümbrecht, Germany). Plasma glucose was assayed using a Beckman Glucose Analyser II (Stevens 1971) and plasma insulin determined by radioimmunoassay (Flatt \& Bailey 1981). All animal studies were carried out in accordance with the UK Animals (Scientific Procedures) Act 1986.

\section{Statistical analysis}

Data are expressed as means \pm S.E.M. and were compared using Student's $t$-test or ANOVA, followed by StudentNewman-Keuls post hoc test. Incremental areas under the curve (AUC) were calculated using a computer generated program employing the trapezoidal rule (Burington 1973) with baseline subtraction. Groups of data were considered to be significantly different if $P<0 \cdot 05$.

\section{Results}

\section{Structural identification of GIP and GIP(3-42)}

GIP and GIP(3-42) were synthesised by solid-phase Fmoc protocols and purified by HPLC. Figure 1 shows the monoisotopic molecular masses obtained for GIP (Fig. 1A) and GIP(3-42) (Fig. 1B) upon ESI-MS analysis. After spectral averaging was performed, prominent multiple charged species $(\mathrm{M}+3 \mathrm{H})^{3+}$ and $(\mathrm{M}+4 \mathrm{H})^{4+}$ were detected from GIP at $m / z 1661 \cdot 6$ and $1246 \cdot 8$, corresponding to intact $M_{\mathrm{r}} 4981 \cdot 8$ and $4983 \cdot 2 \mathrm{Da}$ respectively (Fig. 1A). This corresponds very closely to the theoretical mass 4984.2 Da. Similarly, for GIP(3-42), $(\mathrm{M}+3 \mathrm{H})^{3+}$ and $(\mathrm{M}+4 \mathrm{H})^{4+}$ were detected at $m / z 1583.9$ and $1188 \cdot 1$, corresponding to intact $M_{\mathrm{r}} 4748.7$ and $4748.4 \mathrm{Da}$ respectively (Fig. 1B), which corresponds closely with the theoretical mass of $4746 \cdot 4 \mathrm{Da}$.

\section{In vitro actions of GIP and $\operatorname{GIP}(3-42)$}

Coupling of the receptors to adenylyl cyclase was examined by production of intracellular cAMP after exposure of the GIP receptor transfected CHL cells to GIP and GIP(3-42). GIP dose dependently $\left(10^{-12}\right.$ to $\left.10^{-6} \mathrm{M}\right)$ stimulated cAMP production with a half-maximal stimulatory concentration $\left(\mathrm{EC}_{50}\right)$ value of $18.2 \mathrm{nM}$ (Fig. 2A). In contrast, only very weak stimulation of cAMP production could be observed when GIP(3-42) was exposed to transfected fibroblasts (Fig. 2A). cAMP formation was less than $5 \%$ of the stimulation caused by native GIP even at concentrations as high as $10^{-6} \mathrm{M}$. When incubated in the presence of $10^{-7} \mathrm{M}$ GIP, GIP(3-42) significantly inhibited cAMP production, with maximal inhibition $(75 \cdot 4 \pm 5 \cdot 4 \%)$ observed at $10^{-6} \mathrm{M}$ (Fig. 2B).

Figure 3 shows the effects of GIP and GIP(3-42) on insulin secretion from clonal pancreatic BRIN-BD11 cells. From Fig. 3A, it can be seen clearly that native GIP dose dependently $\left(10^{-11}\right.$ to $\left.10^{-8} \mathrm{M}\right)$ stimulated insulin secretion (1.2- to $1 \cdot 8$-fold; $P<0 \cdot 05$ to $P<0 \cdot 001)$ compared with control incubations $(5.6 \mathrm{mM}$ glucose alone). GIP(342) did not significantly stimulate insulin secretion compared with the native peptide (1.9- to 3.2-fold lower; $P<0 \cdot 001)$. In the presence of stimulatory GIP $\left(10^{-7} \mathrm{M}\right)$, GIP(3-42) dose dependently inhibited insulin release (1.1 - to 1.5 -fold; $P<0.05$ to $P<0.001)$ compared with GIP, with maximal inhibition $(48.8 \pm 6 \cdot 2 \% ; P<0 \cdot 001)$ observed at $10^{-7} \mathrm{M}$ (Fig. 3B).

\section{In vivo actions of GIP and $\operatorname{GIP}(3-42)$}

Consistent with these effects, plasma insulin concentrations of $(o b / o b)$ mice treated with $\operatorname{GIP}(3-42)$ were significantly lowered $(2 \cdot 2$-fold; $P<0 \cdot 001)$ at $60 \mathrm{~min}$ post injection compared with mice treated with GIP alone (Fig. $5 \mathrm{~A})$. Furthermore, the overall insulin response, estimated by AUC was significantly lower $(2 \cdot 1$-fold; $P<0 \cdot 001)$ following administration of $\operatorname{GIP}(3-42)$ compared with GIP-only treated mice (Fig. 5B). As expected, mice treated with GIP alone exhibited significantly improved insulin and glycaemic responses compared with glucose control (Figs 4 and 5). 

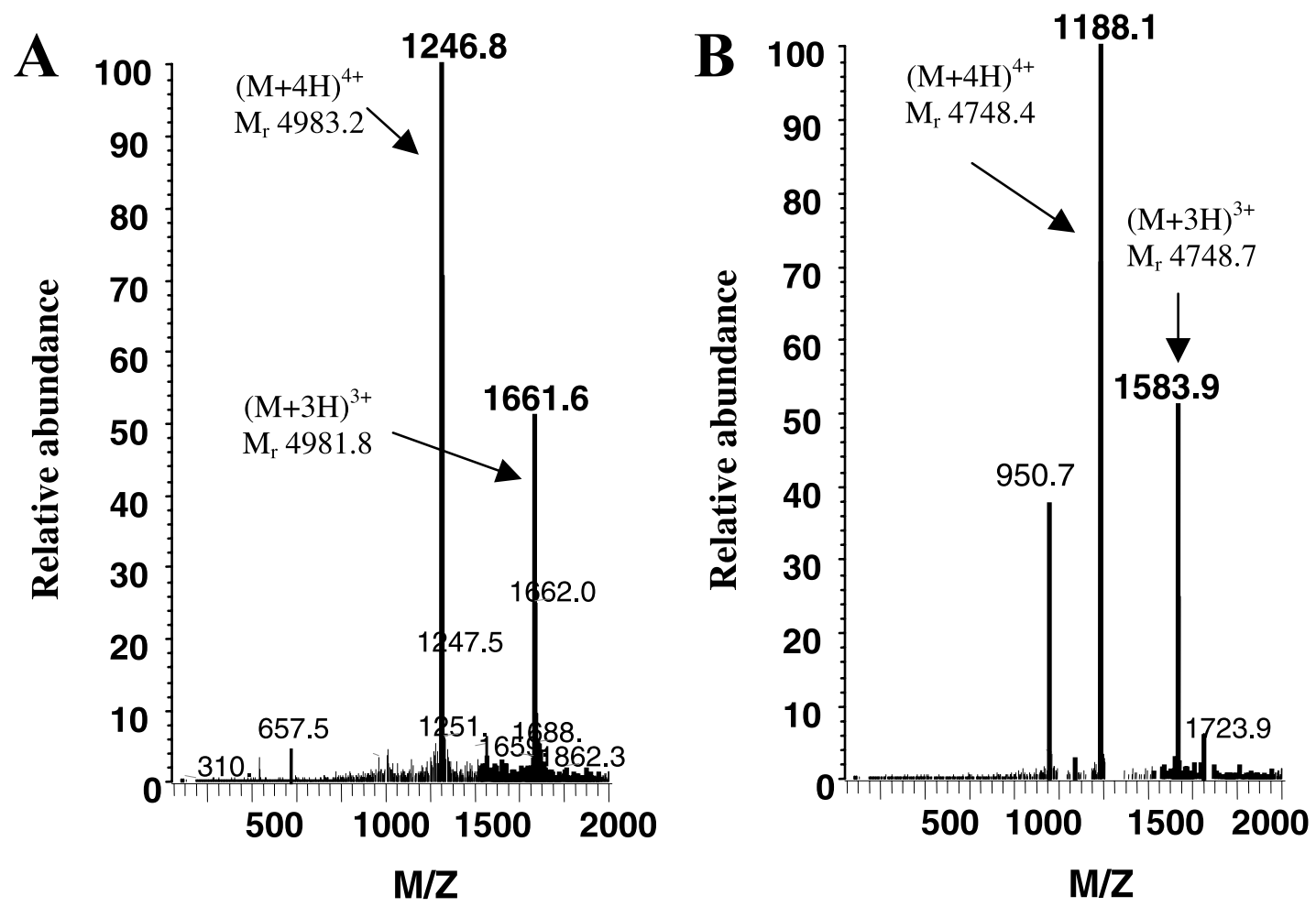

Figure 1 Electrospray ionisation-mass spectrometry (ESI-MS) of GIP (A) and GIP(3-42) (B). The peptides were dissolved (approximately $400 \mathrm{pM}$ ) in $100 \mu \mathrm{l}$ water and applied by direct loop injection to the LC/MS under isocratic conditions. Mass spectra were recorded using a quadripole ion trap mass analyser and collected using full ion scan mode over the mass-to-charge $(\mathrm{m} / \mathrm{z})$ range $150-2000$. The $M_{r}$ of GIP and GIP(3-42) were determined from ESI-MS profiles using prominent multiple charged ions and the following equation: $M_{\mathrm{r}}=i M_{\mathrm{i}}-i M_{\mathrm{h}}$ (see Materials and Methods).

\section{Discussion}

The rapid degradation of GIP by the enzyme dipeptidyl peptidase IV (DPP IV) and consequent short biological half-life (approximately 5-7 min) (Deacon et al. 2000) are major factors which hamper possible therapeutic use of the peptide for type 2 diabetes. The enzyme is ubiquitously expressed in mammalian tissues and organs (Wrenger et al. 2000) and circulates at relatively high concentrations in the blood (Lojda 1979). DPP IV's strict substrate specificity for removing dipeptides from the amino terminus of peptides with penultimate proline, alanine or hydroxyproline residues (Walter et al. 1980) means that, in the case of GIP, the amino-terminal $\mathrm{Tyr}^{1}-\mathrm{Ala}^{2}$ dipeptide is removed producing the metabolite GIP(3-42).

In this study, the effects of the truncated GIP(3-42) fragment on GIP action were examined in vitro and in a commonly employed animal model of obesity-diabetes and enteroendocrine hyperactivity. The ability of GIP(342) to couple to the GIP receptor and stimulate intracellular cAMP production was examined using transfected CHL cells (Gremlich et al. 1995). Native GIP was shown to dose dependently stimulate cAMP production with an
$\mathrm{EC}_{50}$ value of $18.2 \mathrm{nM}$, which is broadly in line with previous studies using this cell line (Gremlich et al. 1995). In comparison, GIP(3-42) demonstrated only very weak agonist activity, reminiscent of the effects of the novel GIP antagonist, $\left(\right.$ Pro $\left.^{3}\right)$ GIP (Gault et al. 2002). Subsequent studies confirmed the antagonistic properties of GIP(3-42) by revealing that the truncated peptide inhibited GIPinduced cAMP production by as much as $75 \cdot 4 \pm 5 \cdot 4 \%$.

Consistent with previous observations using clonal pancreatic BRIN-BD11 cells (O'Harte et al. 1998), GIP induced a concentration-dependent increase of insulin release at physiological glucose concentration. In contrast, GIP(3-42) lacked any significant insulinotropic activity, which corroborates previous findings in the perfused rat pancreas (Brown et al. 1981). However, when incubated with stimulatory GIP $\left(10^{-7} \mathrm{M}\right), \operatorname{GIP}(3-42)$ significantly countered the ability of the native peptide to enhance insulin secretion. An approximate 35\% inhibition was observed with $10^{-8} \mathrm{M} \mathrm{GIP(3-42),} \mathrm{making} \mathrm{the} \mathrm{metabolite}$ comparable to established antagonists ANTGIP and $\left(\right.$ Pro $\left.^{3}\right)$ GIP (Tseng et al. 1996, Gault et al. 2002). These data contrast with early observations where $\operatorname{GIP}(3-42)$ was recorded as being devoid of any antagonistic activity when applied to isolated islets at tenfold higher molar 

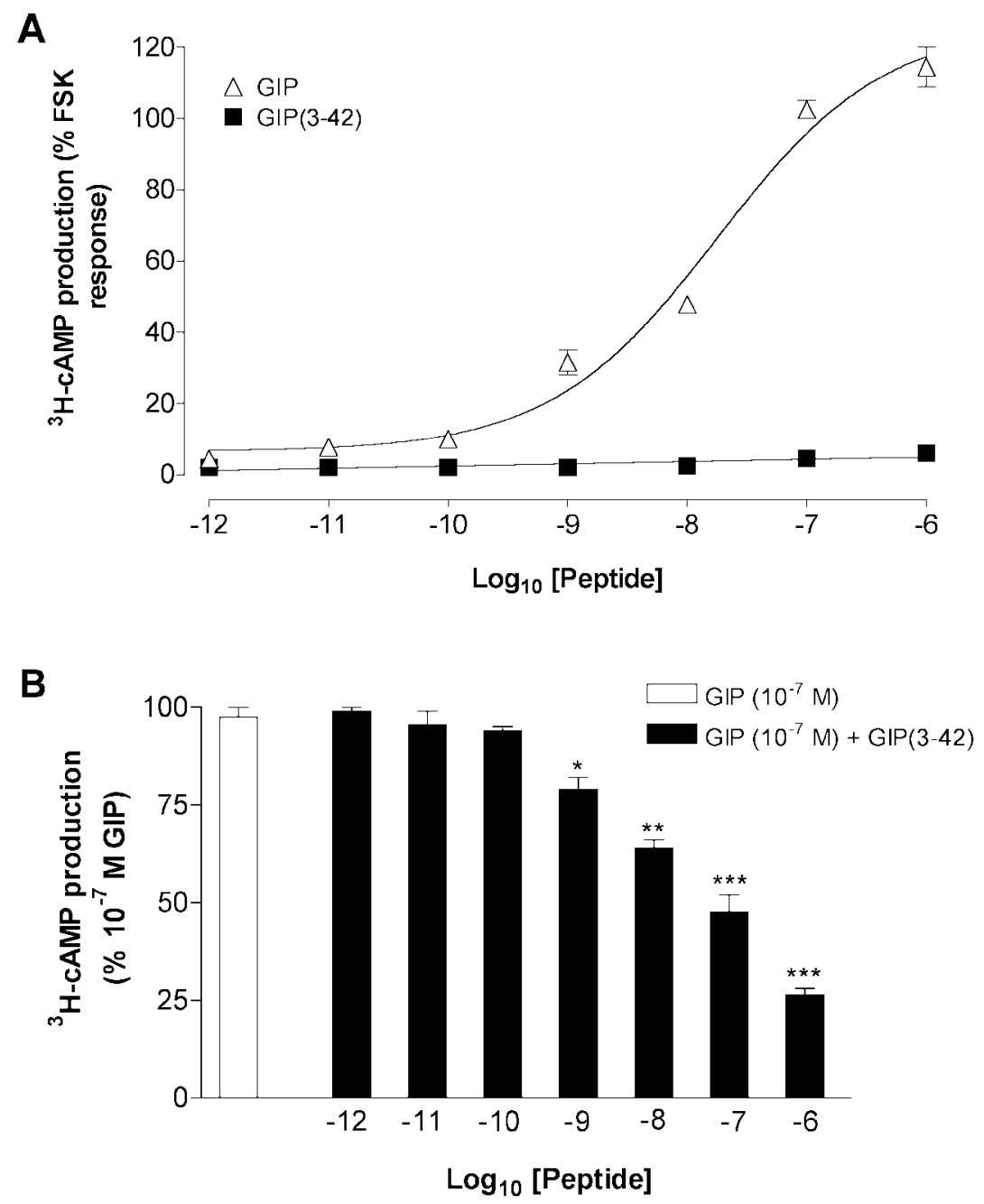

Figure 2 Effects of GIP and GIP(3-42) on CAMP production in GIP receptor-transfected $\mathrm{CHL}$ cells. (A) GIP dose-dependently stimulated cAMP production with an $\mathrm{EC}_{50}$ of $18 \cdot 2 \mathrm{nM}$, whereas GIP(3-42) caused very small increases (5\%). (B) Inhibition of GIP $\left(10^{-7} \mathrm{M}\right)$-stimulated cAMP production by varied concentrations of GIP(3-42). Data are expressed as a percentage of the forskolin $(10 \mu \mathrm{M})$ response. Values are means \pm S.E.M. of 3 observations. ${ }^{*} P<0 \cdot 05,{ }^{* *} P<0 \cdot 01,{ }^{* *} P<0 \cdot 001$ compared with GIP $\left(10^{-7} \mathrm{M}\right)$ control.

concentrations than native peptide (Schmidt et al. 1987). The discrepancy may relate to the use of hyperglycaemic conditions in this earlier study or possibly improvements in peptide synthesis as the present data clearly demonstrate GIP(3-42) as an antagonist of cAMP production and insulin secretion.

To evaluate the biological actions of GIP(3-42) on normal islets and glucose homeostasis in vivo, we employed obese diabetic $(o b / o b)$ mice. This is an extensively studied animal model displaying several abnormalities characteristic of type 2 diabetes, including obesity, insulin resistance, moderate hyperglycaemia and severe hyperinsulinaemia
(Bailey \& Flatt 1982). The present results corroborate previous findings, as GIP displayed significant insulinotropic activity when administered in conjunction with glucose to $(o b / o b)$ mice (Flatt et al. 1984, O'Harte et al. 2000). Such action resulted in a notable moderation in the glycaemic excursion. Consistent with the antagonistic properties of $\operatorname{GIP}(3-42)$ in vitro, $\operatorname{GIP}(3-42)$ significantly countered the insulinotropic and antihyperglycaemic action of GIP in $(o b / o b)$ mice. In fact, administration of GIP(3-42) resulted in a worsening of the glycaemic and insulin responses compared with injection of glucose alone. These results demonstrate that $\operatorname{GIP}(3-42)$ acts 

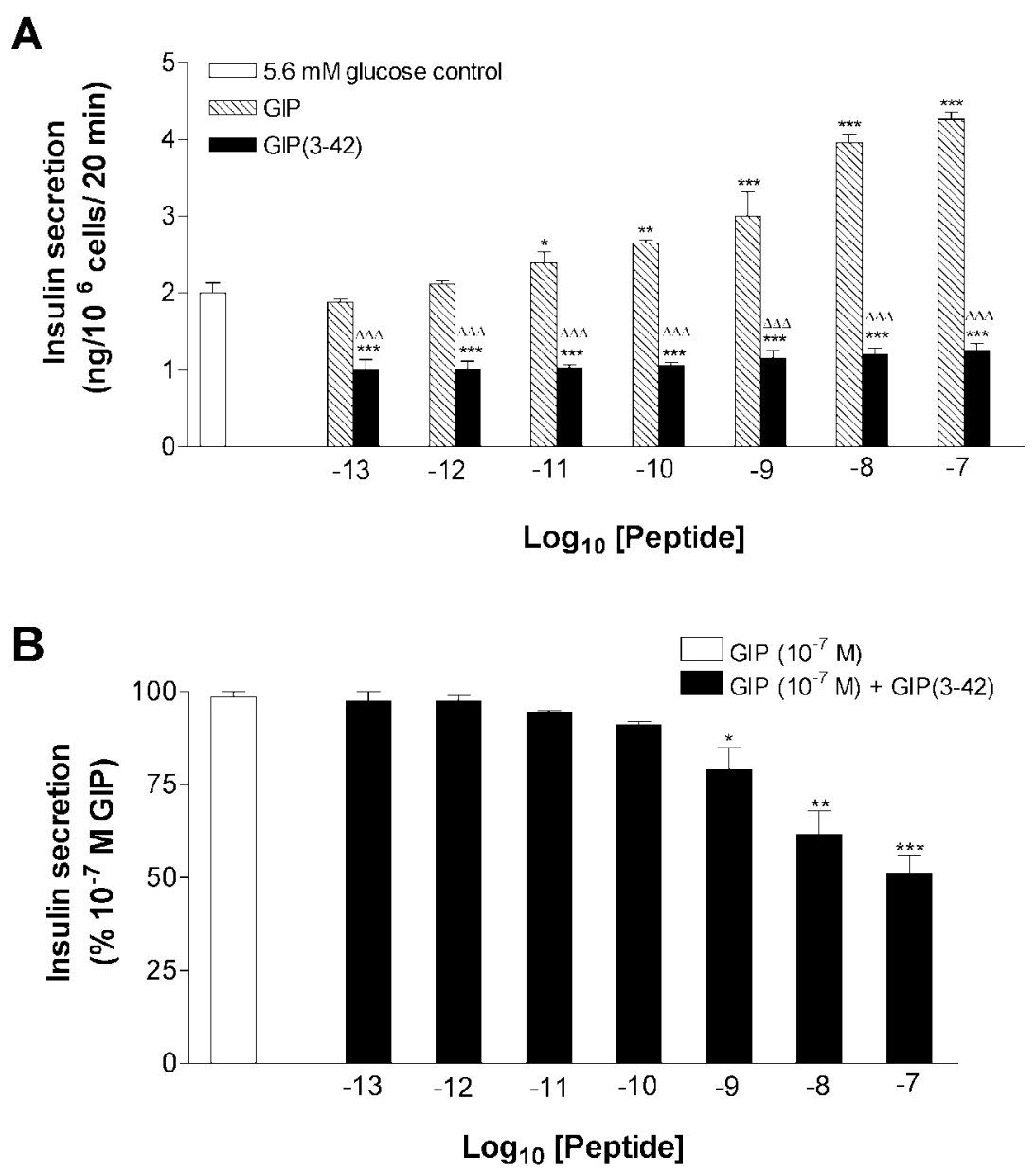

Figure 3 Effects of GIP(3-42) on insulin secretion in clonal pancreatic BRIN-BD11 cells. (A) GIP dose-dependently stimulated insulin secretion, whereas GIP(3-42) lacked significant insulinotropic activity. (B) Inhibition of GIP $\left(10^{-7} \mathrm{M}\right)$-stimulated insulin secretion by varied concentrations of GIP(3-42). Values are means \pm S.E.M. for 8 separate observations. ${ }^{*} P<0 \cdot 05,{ }^{* *} P<0 \cdot 01,{ }^{* *} P<0 \cdot 001$ compared with $5 \cdot 6 \mathrm{mM}$ glucose control. ${ }^{\Delta \Delta \Delta} P<0 \cdot 001$ compared with GIP at the same concentration.

as a potent GIP receptor antagonist in vivo, and that endogenous GIP has a significant permissive effect on glucose-stimulated insulin release in $o b / o b$ mice.

The observation that $\operatorname{GIP}(3-42)$ acts as an antagonist against the native peptide in vivo is significant since, using a specific N-terminally directed GIP radioimmunoassay, it has been shown that up to $80 \%$ of the circulating GIP is in the truncated GIP(3-42) form (Deacon et al. 2000). Therefore, it is likely that antagonism at the GIP receptor by the truncated GIP(3-42) metabolite greatly reduces the biological effectiveness of this glucoincretin hormone, warranting further studies of $\operatorname{GIP}(3-42)$ concentrations in diabetes and different physiological states. The same scenario may also exist for GLP-1, since this peptide has been shown to exhibit an extremely short duration of action when administered subcutaneously to type 2 diabetic patients (Nauck et al. 1996). Consistent with this view, several studies have suggested that the truncated GLP-1 metabolite, GLP-1-(9-36) amide might, in fact, act as a GLP-1 receptor antagonist, acting not only on the pancreatic GLP-1 receptor, but also antagonising the gastrointestinal effects of GLP-1 (Grandt et al. 1994, Knudsen \& Pridal 1996, Wettergren et al. 1998).

The concept that degradation of GIP and GLP-1 to their truncated forms leads to effective antagonists of their respective receptors has formed the basis for the proposition that inhibition of DPP IV may prove useful in the potential treatment of type 2 diabetes (Holst \& Deacon 1998). This has led to the development of several DPP IV inhibitors which have been shown to inhibit N-terminal degradation of both GIP and GLP-1, while simultaneously augmenting the glucose and insulin responses (Balkan et al. 
A
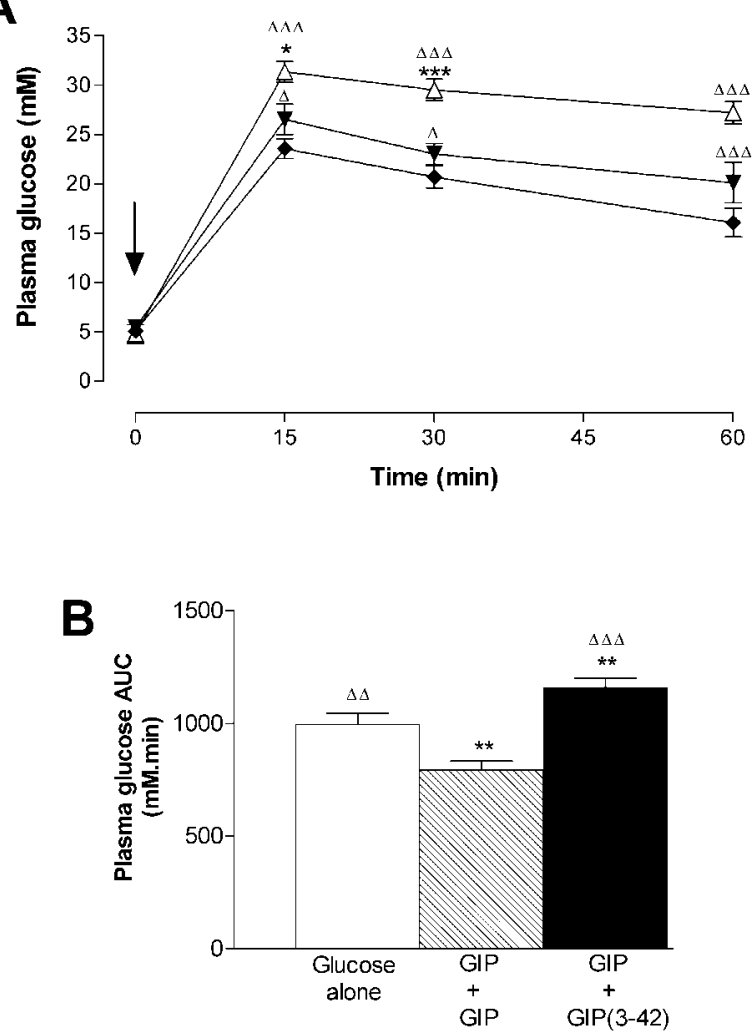

Figure 4 Effects of native GIP and GIP(3-42) on plasma glucose homeostasis in $(o b / o b)$ mice. (A) Plasma glucose concentrations after i.p. administration of glucose alone $(\boldsymbol{\nabla}, 18 \mathrm{mmol} / \mathrm{kg})$ or in combination with either native GIP $(\diamond, 2 \times 25 \mathrm{nmol} / \mathrm{kg})$ or native GIP $(25 \mathrm{nmol} / \mathrm{kg})$ plus GIP $(3-42)(\triangle, 25 \mathrm{nmol} / \mathrm{kg})$. The time of injection is indicated by the arrow (0 min). (B) Plasma glucose AUC values for 0-60 min post injection. Values are means \pm S.E.M. for 8 mice. ${ }^{*} P<0 \cdot 05,{ }^{*} P<0 \cdot 01,{ }^{* * *} P<0 \cdot 001$ compared with glucose alone. ${ }^{\Delta} P<0 \cdot 05,{ }^{\Delta \Delta} P<0 \cdot 01,{ }^{\Delta \Delta \Delta} P<0 \cdot 001$ compared with native GIP.

1999, Ahren et al. 2000, Deacon et al. 2001, Pospisilik et al. 2002). However, due to the presumed side effects of widespread DPP IV inhibition in the mammalian body, this method could prove problematic (Mentlein et al. 1993). Another alternative indirect approach of prolonging GIP or GLP-1 activity would be to structurally modify the molecule itself, thereby conferring the peptide with resistance to DPP IV activity. Since the strict substrate specificity of DPP IV is well characterised, it seems that small alterations at the N-terminus could render GIP and GLP-1 resistant to degradation. Several GIP, GLP-1 and GLP-2 analogues have already been synthesised and their DPP IV stability and biological activity tested (Drucker et al. 1997, Deacon et al. 1998, Siegel et al. 1999, O'Harte et al. 2000, Hinke et al. 2002). No matter which approach is chosen, inhibition of GIP and GLP-1 degradation would not only increase the availability of the biologically active
A
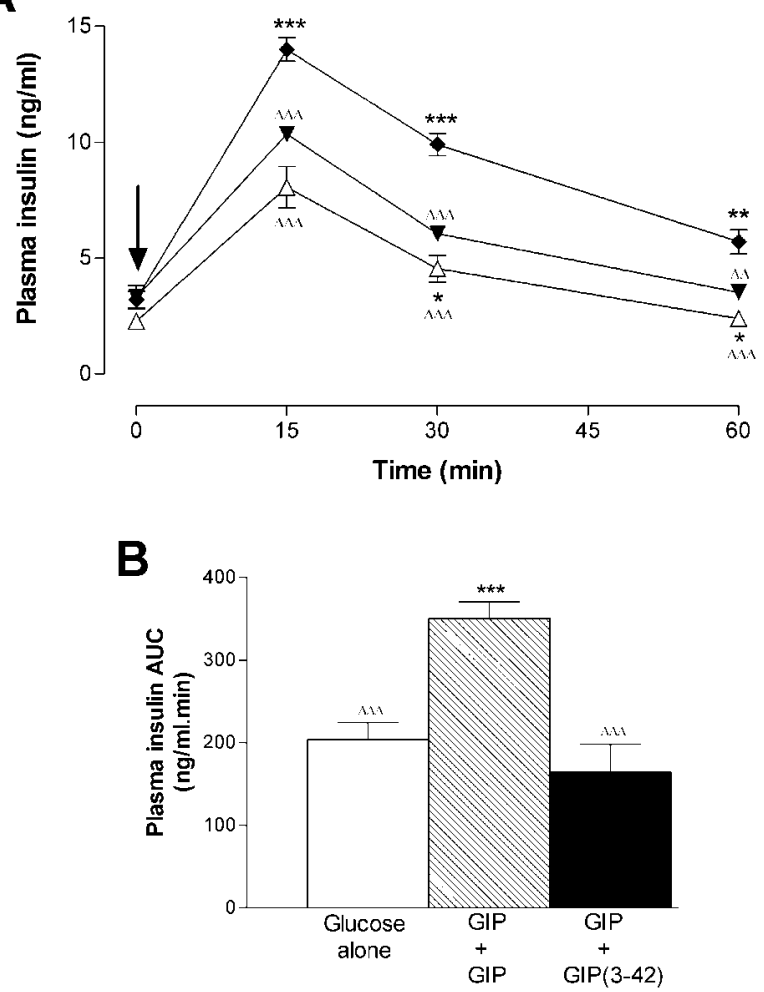

Figure 5 Effects of native GIP and GIP(3-42) on plasma insulin responses in $(\mathrm{ob} / \mathrm{ob})$ mice. (A) Plasma insulin concentrations after i.p. administration of glucose alone $(\boldsymbol{\nabla}, 18 \mathrm{mmol} / \mathrm{kg})$ or in combination with either native GIP $(\diamond, 2 \times 25 \mathrm{nmol} / \mathrm{kg})$ or native GIP $(25 \mathrm{nmol} / \mathrm{kg})$ plus GIP(3-42) $(\triangle, 25 \mathrm{nmol} / \mathrm{kg})$. The time of injection is indicated by the arrow (0 min). (B) Plasma insulin AUC values for $0-60 \mathrm{~min}$ post injection. Values are means \pm S.E.M. for 8 mice. ${ }^{*} P<0 \cdot 05,{ }^{*} P<0 \cdot 01,{ }^{* * *} P<0 \cdot 001$ compared with glucose alone. ${ }^{\Delta \Delta} P<0 \cdot 01,{ }^{\Delta \Delta \Delta} P<0 \cdot 001$ compared with native GIP.

peptide, but would also reduce the effect of the feedback antagonism of the truncated forms at the level of the receptor.

In conclusion, this study has shown that $\mathrm{N}$-terminal degradation of GIP to GIP(3-42) produces a peptide antagonist, which inhibits GIP-stimulated cAMP production and insulin secretion in vitro. Moreover, data presented here demonstrate that GIP(3-42) effectively countered the insulin releasing and antihyperglycaemic actions of native GIP in vivo. This antagonistic activity may have important implications for the use of GIP as a therapeutic agent in diabetes, since $\operatorname{GIP}(3-42)$ interaction with the GIP receptor may be important for regulating GIP activity in vivo.

\section{Acknowledgements}

These studies were supported by the Department of Health and Personal Social Services for Northern Ireland 
and University of Ulster Research Strategy Funding. The authors wish to thank Professor B Thorens (University of Lausanne, Switzerland) for kindly providing transfected CHL cells and Dr C J Bailey (Aston University, Birmingham, UK) for $(o b / o b)$ mice.

\section{References}

Ahren B, Holst JJ, Martensson H \& Balkan B 2000 Improved glucose tolerance and insulin secretion by inhibition of dipeptidyl peptidase IV in mice. European Journal of Pharmacology 404 239-245.

Bailey CJ \& Flatt PR 1982 Influence of genetic background and age on the expression of the obese hyperglycaemic syndrome in Aston ob/ob mice. International Journal of Obesity 6 11-21.

Balkan B, Kwasnik L, Miserendino R, Holst JJ \& Li X 1999 Inhibition of dipeptidyl peptidase IV with NVP-DPP728 increases plasma GLP-1 (7-36 amide) concentrations and improves oral glucose tolerance in obese Zucker rats. Diabetologia 42 1324-1331.

Brown J, Dahl M, Kwauk C, McIntosh C, Otte S \& Pederson R 1981 Actions of GIP. Peptides 2 (Suppl 2) 241-245.

Buchan MT, Polak JM, Capella C, Solcia E \& Pearse AG 1978 Electroimmunocytochemical evidence for the K-cell localization of gastric inhibitory polypeptide (GIP) in man. Histochemistry $\mathbf{5 6}$ 37-44.

Burington RS 1973 Handbook of Mathematical Tables and Formulas. New York: McGraw Hill.

Carlquist MM, Maletti M, Jörnvall H \& Mutt V 1984 A novel form of gastric inhibitory polypeptide (GIP) isolated from bovine intestine using radioreceptor assay. Fragmentation with staphylococcal protease results in GIP 1-3, GIP 4-42, fragmentation with enterokinase in GIP 1-16 and GIP 17-42. European Journal of Pharmacology 145 573-577.

Creutzfeldt W \& Ebert R 1985 New developments in the incretin concept. Diabetologia 28 565-573.

Deacon CF, Knudsen LB, Madsen K, Wiberg FC, Jacobsen O \& Holst JJ 1998 Dipeptidyl peptidase IV resistant analogues of glucagon-like peptide- 1 which have extended metabolic stability and improved biological activity. Diabetologia 41 271-278.

Deacon CF, Nauck MA, Meier J, Hücking K \& Holst JJ 2000 Degradation of endogenous and exogenous gastric inhibitory polypeptide in healthy and in type 2 diabetic subjects as revealed using a new assay for the intact peptide. Journal of Clinical Endocrinology and Metabolism 85 3575-3581.

Deacon CF, Danielsen P, Klarskov L, Olesen M \& Holst JJ 2001 Dipeptidyl peptidase IV inhibition reduces the degradation and clearance of GIP and potentiates its insulinotropic and antihyperglycaemic effects in anesthetised pigs. Diabetes $\mathbf{5 0}$ 1588-1597.

Drucker DJ, DeForest L \& Brubaker PL 1997 Intestinal response to growth factors administered alone or in combination with human $\left[\mathrm{Gly}^{2}\right]$ glucagon-like peptide 2. American Journal of Physiology 273 G1252-G1262.

Fields GB \& Noble RL 1990 Solid phase peptide synthesis utilizing 9-fluorenylmethoxycarbonyl amino acids. International Journal of Peptide and Protein Research 35 161-214.

Flatt PR \& Bailey CJ 1981 Abnormal plasma glucose and insulin responses in heterozygous lean $(o b /+)$ mice. Diabetologia 20 573-577.

Flatt PR, Bailey CJ, Kwasowski P, Page T \& Marks V 1984 Plasma immunoreactive gastric inhibitory polypeptide in obese hyperglycaemic (ob/ob) mice. Journal of Endocrinology 101 249-256.

Gault VA, O'Harte FPM, Harriott P \& Flatt PR 2002 Characterization of the cellular and metabolic effects of a novel enzyme-resistant antagonist of glucose-dependent insulinotropic polypeptide. Biochemical and Biophysical Research Communications 290 1420-1426.
Gelling R, Coy D, Pederson R, Wheeler M, Hinke S, Kwan T \& McIntosh C 1997 GIP (6-30 amide) contains the high affinity binding region of GIP and is a potent inhibitor of GIP 1-42 action in vitro. Regulatory Peptides 69 151-154.

Grandt D, Sieberg B, Sievert J, Schimiczek M, Becker U, Holtmann B, Layer P, Reeve JR, Eysselein VE, Goebell H \& Müller M 1994 Is GLP-1(9-36)amide an endogenous antagonist of GLP-1 receptors? Digestion 55 302A (Abstract).

Gremlich S, Porret A, Hani EH, Cherif D, Vionnet N, Froguel P \& Thorens B 1995 Cloning, functional expression, and chromosomal localization of the human pancreatic islet glucose-dependent insulinotropic polypeptide receptor. Diabetes 44 1202-1208.

Hinke SA, Manhart S, Pamir N, Demuth H-U, Gelling RW, Pederson RA \& McIntosh CHS 2001 Identification of a bioactive domain in the amino terminus of glucose-dependent insulinotropic polypeptide (GIP). Biochimica et Biophysica Acta 1547 143-155.

Hinke SA, Gelling RW, Pederson RA, Manhart S, Nian C, Demuth H-U \& McIntosh CHS 2002 Dipeptidyl peptidase IV-resistant $\left[\mathrm{D}-\mathrm{Ala}^{2}\right]$ glucose-dependent insulinotropic polypeptide (GIP) improves glucose tolerance in normal and obese diabetic rats. Diabetes $\mathbf{5 1}$ 652-661.

Holst JJ \& Deacon CF 1998 Inhibition of the activity of dipeptidylpeptidase IV as a treatment for type 2 diabetes. Diabetes $\mathbf{4 7}$ 1663-1670.

Jörnvall H, Carlquist M, Kwauk S, Otte SC, McIntosh CHS, Brown JC \& Mutt V 1981 Amino acid sequence heterogeneity of gastric inhibitory polypeptide (GIP). FEBS Letters 123 205-210.

Knudsen LB \& Pridal L 1996 Glucagon-like peptide-1-(9-36) amide is a major metabolite of glucagon-like peptide-1-(7-36) amide after in vivo administration to dogs, and it acts as an antagonist on the pancreatic receptor. European Journal of Pharmacology 318 429-435.

Lojda Z 1979 Studies on dipeptidyl(amino)peptidase IV (glycyl-proline naphthylamidase) II blood vessels. Histochemistry 59 153-166.

McClenaghan NH, Barnett CR, Ah-Sing E, Abdel-Wahab YHA, O'Harte FPM, Yoon T-W, Swanston-Flatt SK \& Flatt PR 1996 Characterisation of a novel glucose-responsive insulin-secreting cell line, BRIN-BD11, produced by electrofusion. Diabetes $\mathbf{4 5}$ $1132-1140$.

Maletti M, Carlquist M, Portha B, Kergoat M, Mutt V \& Rosselin G 1986 Structural requirements for gastric inhibitory polypeptide (GIP) receptor binding and stimulation of insulin release. Peptides 7 (Suppl 1) 75-78.

Maletti M, Altman JJ, Hoa DH, Carlquist M \& Rosselin G 1987 Evidence of functional gastric inhibitory polypeptide (GIP) receptors in human insulinoma. Binding of synthetic human GIP 1-31 and activation of adenylate cyclase. Diabetes 36 1336-1340.

Mentlein R, Gallwitz B \& Schmidt WE 1993 Dipeptidyl-peptidase IV hydrolyses gastric inhibitory polypeptide, glucagon-like peptide-1-(7-36)amide, peptide histidine methionine and is responsible for their degradation in human serum. European Journal of Biochemistry 214 829-835.

Morgan LM 1996 The metabolic role of GIP: physiology and pathophysiology. Biochemical Society Transactions 24 585-591.

Moroder L, Hallett A, Thamm P, Wilschowitz L, Brown JC \& Wunsch E 1978 Studies on gastric inhibitory polypeptide: Synthesis of the octatricontapeptide GIP(1-38) with full insulinotropic activity. Scandinavian Journal of Gastroenterology 13 (Suppl 46) 129 (Abstract).

Morrow GW, Kieffer TJ, McIntosh CHS, MacGillivray RTA, Brown JC, StPierre S \& Pederson RA 1996 The insulinotropic region of gastric inhibitory polypeptide: fragment analysis suggests the bioactive site lies between residues 19 and 30. Canadian Journal of Physiology and Pharmacology 74 65-72.

Nauck MA, Wollschläger D, Werner J, Holst JJ, Ørskov C, Creutzfeldt W \& Willms B 1996 Effects of subcutaneous glucagon-like peptide 1 (GLP-1 [7-36 amide]) in patients with type 2 diabetes. Diabetologia 39 1546-1553. 
O'Harte FPM, Abdel-Wahab YHA, Conlon JM \& Flatt PR 1998 Amino terminal glycation of gastric inhibitory polypeptide enhances its insulinotropic action on clonal pancreatic B-cells. Biochimica et Biophysica Acta 1425 319-327.

O'Harte FPM, Mooney MH, Kelly CMN \& Flatt PR 2000 Improved glycaemic control in obese diabetic $o b / o b$ mice using N-terminally modified gastric inhibitory polypeptide. Journal of Endocrinology 165 639-648.

Pederson RA, Mochizuki T, Yanaihara C, Yanaihara N \& Brown JC 1990 Reduced somatostatinotropic effect of a GIP fragment (pGIP(1-30)-NH $\mathrm{NH}_{2}$ ) with insulinotropic activity. Diabetes $\mathbf{4 6}$ (Suppl 1) 86 (Abstract).

Pospisilik JA, Stafford SG, Demuth H-U, Brownsey R, Parkhouse W, Finegood DT, McIntosh CHS \& Pederson RA 2002 Long-term treatment with the dipeptidyl peptidase IV inhibitor P32/98 causes sustained improvements in glucose tolerance, insulin sensitivity, hyperinsulinemia, and $\beta$-cell glucose responsiveness in VDF $(f a / f a)$ Zucker rats. Diabetes 51 943-950.

Rossowski WJ, Zacharia S, Mungan Z, Ozmen V, Ertan A, Baylor LM, Jiang N-Y \& Coy DH 1992 Reduced gastric acid inhibitory effect of a $\mathrm{pGIP}(1-30) \mathrm{NH}_{2}$ fragment with potent pancreatic amylase inhibitory activity. Regulatory Peptides 39 9-17.

Sandberg E, Ahren B, Tendler D, Carlquist M \& Effendic S 1986 Potentiation of glucose induced insulin secretion in the perfused rat pancreas by porcine GIP (gastric inhibitory polypeptide), bovine GIP, and bovine GIP(1-39). Acta Physiologica Scandinavica 127 323-326.

Schmidt WE, Siegel EG, Kümmel H, Gallwitz B \& Creutzfeldt W 1987 Commercially available preparations of porcine glucose-dependent insulinotropic polypeptide (GIP) contain a biologically inactive GIP-fragment and cholecystokinin-33/-39. Endocrinology 120 835-837.

Siegel EG, Gallwitz B, Scharf G, Mentlein R, Morys-Wortmann C, Fölsch UR, Schrezenmeir J, Drescher K \& Schmidt WE 1999 Biological activity of GLP-1 analogues with $\mathrm{N}$ terminal modifications. Regulatory Peptides 79 93-102.
Stevens JF 1971 Determination of glucose by an automatic analyser. Clinica Chemica Acta 32 199-201.

Takeda J, Seino Y, Tanaka K-I, Fukumoto H, Kayano T, Takahashi H, Mitani T, Kurono M, Suzuki T, Tobe T \& Imura H 1987 Sequence of an intestinal cDNA encoding gastric inhibitory polypeptide precursor. PNAS 84 7005-7008.

Thulesen J, Knudsen LB, Hartmann B, Hastrup S, Kissow H, Jeppesen PB, Ørskov C, Holst JJ \& Poulsen SS 2002 The truncated metabolite GLP-2 (3-33) interacts with the GLP 2 receptor as a partial agonist. Regulatory Peptides 103 9-15.

Tseng C-C, Kieffer TJ, Jarboe LA, Usdin TB \& Wolfe MM 1996 Postprandial stimulation of insulin release by glucose-dependent insulinotropic polypeptide (GIP). Effect of a specific glucosedependent insulinotropic polypeptide receptor antagonist in the rat. Journal of Clinical Investigation 98 2440-2445.

Walter R, Simmons WH \& Yoshimoto T 1980 Proline-specific endoand exopeptidases. Molecular and Cellular Biochemistry 30 111-127.

Wettergren A, Wøjdemann M \& Holst JJ 1998 Glucagon-like peptide-1 (7-36)amide's inhibitory effect on antral motility is antagonised by its N-terminally truncated glucagon-like peptide-1 (9-36) amide. Peptides 19 877-882.

Widmann C, Bürki E, Dolci W \& Thorens B 1993 Signal transduction by the cloned glucagon-like peptide-1 receptor: comparison with signaling by the endogenous receptors of $\beta$ cell lines. Molecular Pharmacology 45 1029-1035.

Wrenger S, Faust J, Mrestani-Klaus C, Fengler A, Stöckel-Maschek A, Lorey S, Kähne T, Brandt W, Neubert K, Ansorge S \& Reinhold D 2000 Down regulation of T-cell activation following inhibition of dipeptidyl peptidase IV/CD26 by the N-terminal part of the thromboxane A2 receptor. Journal of Biological Chemistry 275 22180-22186.

Received 13 May 2002

Accepted 4 July 2002 